\title{
Synthesis and Crystal Structure Characterization of Zinc (II) Tetronic Acid Complexes
}

\author{
K. C. Prousis, ${ }^{1}$ G. Athanasellis, ${ }^{1,2}$ V. Stefanou, ${ }^{1,2}$ D. Matiadis, ${ }^{1}$ E. Kokalari, ${ }^{1}$ \\ O. Igglessi-Markopoulou, ${ }^{1}$ V. McKee, ${ }^{3}$ and J. Markopoulos ${ }^{2}$
}

${ }^{1}$ Laboratory of Organic Chemistry, School of Chemical Engineering, National Technical University of Athens, 15773, Athens, Greece

${ }^{2}$ Laboratory of Inorganic Chemistry, Department of Chemistry, University of Athens, Panepistimiopolis, 15771 Athens, Greece

${ }^{3}$ Chemistry Department, University of Loughborough, Leicestershire LE11 3TU, UK

Correspondence should be addressed to J. Markopoulos, jmmarko@chem.uoa.gr

Received 13 September 2010; Accepted 18 October 2010

Academic Editor: Spyros Perlepes

Copyright ( $) 2010$ K. C. Prousis et al. This is an open access article distributed under the Creative Commons Attribution License, which permits unrestricted use, distribution, and reproduction in any medium, provided the original work is properly cited.

\begin{abstract}
The synthesis and characterization of two new tetronic acid zinc (II) complexes of the empirical formulae $\left[\mathrm{Zn}(\mathrm{L}-\mathrm{H})_{2}\left(\mathrm{H}_{2} \mathrm{O}\right)_{2}\right]$ (1) and $\left[\mathrm{Zn}(\mathrm{L}-\mathrm{H})_{2}\left(\mathrm{H}_{2} \mathrm{O}\right)(\mathrm{MeOH})\right] \mathrm{H}_{2} \mathrm{O}(2)$ found within the same crystal are reported. The zinc ions bind through alkoxide and carbonyl groups of the ligand 3-methoxycarbonyl-5-phenyl tetronic acid (LH) as indicated by ${ }^{1} \mathrm{H}$ NMR and X-ray crystallographic studies. These complexes promote intra- and intermolecular interactions, such as hydrogen bonding and $\pi$ stacking, giving place to the formation of molecular aggregates.
\end{abstract}

\section{Introduction}

Tetronic acid derivatives, tetrahydrofurane-2,4-diones (Scheme 1), represent an important class of oxygen 5 -membered heterocyclic compounds containing the $\beta$ diketonate moiety [1]. A classical example of this type of structure is the molecule of ascorbic acid (vitamin C). These compounds are structural motifs in many natural products [2] exhibiting a wide range of biological activities including antibiotic, antiviral, antineoplastic, and anticoagulant activity [3]. Recently, 3-carboxamide tetronic acids were investigated as inhibitors of undecaprenyl pyrophosphate synthase (UPPS) for use as antimicrobial agents [4] while compounds which have been isolated from natural products and exhibit such activity are tetronasin [5], RK-682 (3alkanoyl-5-hydroxymethyl tetronic acid) $[6,7]$, and the well-known family of compounds named vulpinic acids $[8,9]$. In addition, several nonnatural 3 -functionalized tetronic acids have been reported as antioxidant and anti-inflammatory compounds [6].

The interesting biological and structural diversity of these compounds has raised the attention of chemists and biologists by reason of their challenging structural complexity and their high affinity to various sorts of "biological effectors" ranging from simple "metal cations" to complex enzymes [10].

Tetronates, containing the $\beta$-diketo acid pharmacophoric motif, could be involved as model ligands for binding with divalent metal ions, which are critical cofactors at the enzyme catalytic site [11].

The coordination chemistry of zinc (II) $\beta$-diketonates has been extensively explored as a model compound for the understanding of the chemistry of zinc (II) complexes, where a metal-oxygen bond is formed. The most important and best role of zinc is as a structural cofactor in metalloproteins. Even more, the metal $\beta$-diketonates including zinc (II) complexes are a promising class of compounds as inhibitors of HIV-1 and of integrase (IN), since the active site of the enzyme interacts with the metal diketonates [12]. It is well known that zinc (II) activates essential enzymes such as carboxypeptidase or alcohol dehydrogenase providing a complex with the active site. Also, the zinc ion is an important structural component in proteins in nucleic acid binding ("zinc-fingers" transcription factors) [13, 14]. Meanwhile, zinc (II) ions are directly associated with the regulation of gene expression through metalloregulatory proteins. In addition, zinc (II) ions are also present in most DNA and RNA polymerases [15]. Moreover, the 
<smiles>O=C1OC(=O)C2=C1OC[C@H]2c1ccccc1</smiles>

A<smiles></smiles>

C<smiles>COc1occ2c1C(=O)OC2c1ccccc1</smiles><smiles>[B]=C</smiles>

B<smiles></smiles>

D

Scheme 1: 3-Methoxycarbonyl-5-phenyltetronic acid.
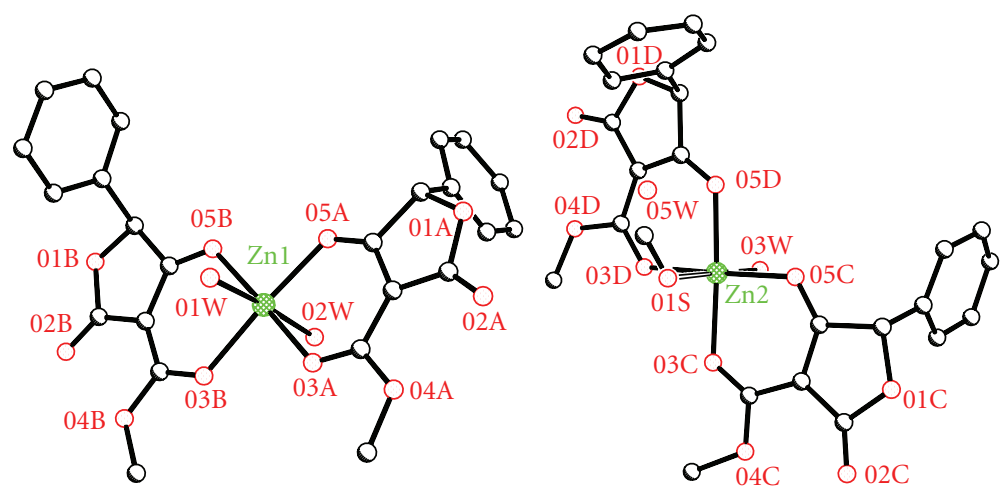

Figure 1: X-ray structure of the two independent complexes in the asymmetric unit of the metal complex, Zn1 and Zn2.

metalloneurochemistry of zinc (II) is of substantial current interest; zinc and d-block metals are emerging as significant players in neurophysiology, aging, and neuropathology [16]. Zinc is the second most abundant d-block metal ion in the human brain, and its distribution varies with relatively high concentrations found in the hippocampus [17]. It is interesting to point out that the tetracoordinated zinc (II) complexes are a promising class of versatile synthons to supramolecular architectures, since the driving force to aggregation occurs through the metal center [18], hydrogen bonds, and $\pi$-stacking $[19,20]$. Recent development on the design and synthesis of zinc (II) fluorescent probes including chemosensors with fluorogenic agents and biosensors has been done and referred [15].

In the course of our research program on transition metal complexes with heterocyclic scaffolds containing the $\beta$-diketo functionality [21-23], we reported in a recent work the coordination model of tetronic acids with $\mathrm{Cu}$ (II) and $\mathrm{Co}$ (II) ions $[10,24]$.

In the present paper, we report a detailed investigation of new zinc (II) complexes, $\left[\mathrm{Zn}(\mathrm{L}-\mathrm{H})_{2}\left(\mathrm{H}_{2} \mathrm{O}\right)_{2}\right](\mathbf{1})$ and $[\mathrm{Zn}(\mathrm{L}-$ $\left.\mathrm{H})_{2}\left(\mathrm{H}_{2} \mathrm{O}\right)(\mathrm{MeOH})\right] \mathrm{H}_{2} \mathrm{O}(2)$, involving the $\beta$-diketo-tetronic acids as "model ligands". The structure and "supramolecular" arrangements of the isolated complexes have been investigated by single crystal X-ray crystallography.

The "ligand molecules" have a proton adjacent to the carbonyl group and consequently can exhibit enol-enol tautomerism as shown in Scheme 1.

\section{Experimental}

2.1. Materials and Instruments. All reagents were purchased from Aldrich, Fluka, and Acros and were used without further purification. Dry THF was distilled from $\mathrm{Na} / \mathrm{Ph}_{2} \mathrm{CO}$. 
TABle 1: Crystal data, structure refinement for $[\mathrm{Zn}(\mathrm{L}-$ $\left.\mathrm{H})_{2}\left(\mathrm{H}_{2} \mathrm{O}\right)_{2}\right]\left[\mathrm{Zn}(\mathrm{L}-\mathrm{H})_{2}\left(\mathrm{H}_{2} \mathrm{O}\right)(\mathrm{MeOH})\right] \mathrm{H}_{2} \mathrm{O}$.

\begin{tabular}{|c|c|}
\hline Empirical formula & $\mathrm{C}_{24.25} \mathrm{H}_{23} \mathrm{O}_{12.25} \mathrm{Zn}$ \\
\hline Formula weight & 575.80 \\
\hline Temperature & $150(2) \mathrm{K}$ \\
\hline Wavelength & $0.68840 \AA$ \\
\hline Crystal system & Monoclinic \\
\hline Space group & $\mathrm{C} 2$ \\
\hline \multirow{3}{*}{ Unit cell dimensions } & $\mathrm{a}=15.274(7) \AA, \alpha=90^{\circ}$ \\
\hline & $\begin{array}{l}\mathrm{b}=8.812(4) \AA, \beta= \\
97.664(4)^{\circ}\end{array}$ \\
\hline & $\begin{array}{l}\mathrm{c}=39.525(18) \AA, \gamma= \\
90^{\circ} .\end{array}$ \\
\hline Volume & $5272(4) \AA^{3}$ \\
\hline $\mathrm{Z}$ & 8 \\
\hline Density (calculated) & $1.451 \mathrm{Mg} / \mathrm{m}^{3}$ \\
\hline Absorption coefficient & $0.994 \mathrm{~mm}^{-1}$ \\
\hline $\mathrm{F}(000)$ & 2372 \\
\hline Crystal size & $0.16 \times 0.10 \times 0.02 \mathrm{~mm}^{3}$ \\
\hline Crystal description & colourless plate \\
\hline Theta range for data collection & 2.59 to $25.00^{\circ}$ \\
\hline Index ranges & $\begin{array}{l}-18 \leq h \leq 18,-10 \leq k \leq \\
10,-48 \leq 1 \leq 48\end{array}$ \\
\hline Reflections collected & 14618 \\
\hline Independent reflections & $8420[R($ int $)=0.0388]$ \\
\hline Completeness to theta $=25.00^{\circ}$ & $83.4 \%$ \\
\hline Absorption correction & $\begin{array}{l}\text { Semi-empirical from } \\
\text { equivalents }\end{array}$ \\
\hline Max. and min. transmission & 0.9804 and 0.8571 \\
\hline Refinement method & $\begin{array}{l}\text { Full-matrix least-squares } \\
\text { on } \mathrm{F}^{2}\end{array}$ \\
\hline Data/restraints/parameters & $8420 / 696 / 704$ \\
\hline Goodness-of-fit on $F^{2}$ & 1.132 \\
\hline Final $R$ indices $[\mathrm{I}>2 \operatorname{sigma}(\mathrm{I})]$ & $\begin{array}{l}R_{1}=0.0895, w R_{2}= \\
0.2373\end{array}$ \\
\hline$R$ indices (all data) & $\begin{array}{l}R_{1}=0.0928, w R_{2}= \\
0.2396\end{array}$ \\
\hline Absolute structure parameter & $0.17(2)$ \\
\hline Largest diff. peak and hole & 1.905 and -0.959 e..$\AA^{-3}$ \\
\hline
\end{tabular}

Melting points were determined on a Gallenkamp MFB595 melting point apparatus and are uncorrected. IR spectra were recorded on a Jasco 4200 FTIR spectrometer. NMR spectra were recorded on a Varian Gemini-2000 $300 \mathrm{MHz}$ spectrometer operating at $300 \mathrm{MHz}\left({ }^{1} \mathrm{H}\right)$ and $75 \mathrm{MHz}\left({ }^{13} \mathrm{C}\right)$. Chemical shifts are reported in ppm relative to DMSO- $\mathrm{d}_{6}$ $\left({ }^{1} \mathrm{H}: \delta=2.50,{ }^{13} \mathrm{C}: \delta=77.16\right)$. J values are given in $\mathrm{Hz}$.

The X-ray crystals were obtained from a solution of methanol diffused with diethyl ether. Data were collected at $150(2) \mathrm{K}$ on a beamline 9.8 of the Synchrotron Radiation Source, Daresbury using a very thin plate but the mosaicity was still high. The structure was solved by direct methods and refined on $F^{2}$ using all the reflections. All the nonhydrogen atoms were refined using anisotropic atomic displacement parameters and hydrogen atoms were inserted at calculated positions using a riding model.

\subsection{Compound Preparation}

2.2.1. 3-Methoxycarbonyl-5-Phenyl Tetronic Acid. The ligand was prepared, purified and characterized following our research group's method [25-27].

White solid (78\%), m.p. $188-189^{\circ} \mathrm{C}$; (Anal. Found: C, 61.60; H, 4.21. Calc. for $\mathrm{C}_{12} \mathrm{H}_{10} \mathrm{O}_{5}$ : C, 61.54; $\mathrm{H}, 4.27 \%$ ); IR $(\mathrm{KBr}) \nu_{\max } / \mathrm{cm}^{-1}(\mathrm{C}=\mathrm{O}) 1759,1716,(\mathrm{C}=\mathrm{C}) 1610 .{ }^{1} \mathrm{H}-\mathrm{NMR}$ $\delta_{\mathrm{H}}\left(\mathrm{ppm}, \mathrm{DMSO}-\mathrm{d}_{6}\right): 3.64\left(3 \mathrm{H}, \mathrm{s}, \mathrm{COOCH}_{3}\right), 5.67(1 \mathrm{H}, \mathrm{s}$, $\mathrm{CH}$ ring), 7.28-7.42 (5H, m, aromatic protons), 8.65 (enolic $\mathrm{OH}) .{ }^{13} \mathrm{C}-\mathrm{NMR} \delta_{\mathrm{C}}\left(\mathrm{ppm}, \mathrm{DMSO}-\mathrm{d}_{6}\right): 50.7\left(\mathrm{COOCH}_{3}\right)$, 78.8 (C-5), 90.6 (C-3), 127.3/128.8/129.1/135.1 (aromatic carbons), 162.1 (C-6), 69.3 (C-2), 186.9 (C-4).

2.2.2. General Method of Preparation of the Complexes. The synthesis of the complexes was accomplished by mixing the ligand $(2 \mathrm{eq})$ with zinc acetate $\left[\mathrm{Zn}\left(\mathrm{OCOCH}_{3}\right)_{2} \cdot 2 \mathrm{H}_{2} \mathrm{O}\right.$, 1 eq.] in methanol and refluxing the solution for about 2 hours. The resulting solution was evaporated up to a small volume and the precipitate deposited was collected by filtration, washed with cold methanol, diethyl ether and dried in vacuo over $\mathrm{P}_{2} \mathrm{O}_{5}$. The structural elucidation of the complex isolated was accomplished by IR and NMR spectroscopy as well as X-ray Crystallography. X-ray quality crystals were obtained from a solution of methanol diffused with ether.

White solid (67\%); (Anal. Found: C, 50.53; H, 4.05; Calc. For $\mathrm{Zn}_{2} \mathrm{C}_{48.5} \mathrm{H}_{47} \mathrm{O}_{25}$ : C, 50.34; H, 4.06\%). IR ( $\mathrm{KBr}$ ) $v_{\max } / \mathrm{cm}^{-1}(\mathrm{OH}) 3654 \mathrm{w}, 3188 \mathrm{br},(\mathrm{C}=\mathrm{O}$ and $\mathrm{C}=\mathrm{C}) 1732 \mathrm{~s}$, $1650 \mathrm{~s}, 1575 \mathrm{~s}, 1480 \mathrm{~s}, 1419 \mathrm{~m},(\mathrm{Zn}-\mathrm{O}) 472 \mathrm{w}, 428 \mathrm{w} .{ }^{1} \mathrm{H}-$ NMR $\delta_{\mathrm{H}}\left(\mathrm{ppm}, \mathrm{DMSO}-\mathrm{d}_{6}\right): 3.59\left(\mathrm{~s}, 3 \mathrm{H}, \mathrm{COOCH}_{3}\right), 5.42$ (s, $1 \mathrm{H}), 7.26-7.35(\mathrm{~m}, 5 \mathrm{H}$, aromatic protons), $3.16-3.18$ (d, $\mathrm{CH}_{3}$ methanol), 4.08-4.10 (q, OH, methanol). ${ }^{13} \mathrm{C}-\mathrm{NMR} \delta_{\mathrm{C}}$ (ppm, DMSO-d $\left.\mathrm{d}_{6}\right): 48.6\left(\mathrm{COOCH}_{3}\right), 80.4(\mathrm{C}-5), 84.3(\mathrm{C}-3)$, 126.5/128.2/128.3/136.7 (aromatic carbons), 168.5 (C-6), 172.3 (C-2), 195.1 (C-4).

2.3. X-Ray Crystallography. Parameters for data collection and refinement are summarized in Table 1.

\section{Results and Discussion}

3.1. Synthetic Comments, NMR and IR Spectra. The tetronic acid ligand precursor containing the 5-phenyl group (Scheme 1) was synthesized according to a new methodology presented by our group [25-27]. The methodology which was chosen to be followed has the advantages of small reaction times and isolation of products in good yields and satisfactory purity. Moreover, it is stereoselective; therefore, it could be followed in case of other chiral tetronic acids. This strategy is very helpful in situations where chiral molecules are to be used as ligands in coordination chemistry. The reaction of 3-methoxycarbonyl-5-phenyl tetronic acid with zinc (II) acetate gave the bis ligand Zn (II) complexes. The new complexes were characterized by NMR and IR Spectroscopy, elemental analysis, and X-ray crystallography. The 
TABLE 2: Selected bond lengths $[\AA]$ and angles $\left[^{\circ}\right]$ for $\left[\mathrm{Zn}(\mathrm{L}-\mathrm{H})_{2}\left(\mathrm{H}_{2} \mathrm{O}\right)_{2}\right]\left[\mathrm{Zn}(\mathrm{L}-\mathrm{H})_{2}\left(\mathrm{H}_{2} \mathrm{O}\right)(\mathrm{MeOH})\right] \mathrm{H}_{2} \mathrm{O}$.

\begin{tabular}{|c|c|c|c|}
\hline Bond & Bond length & Bond & Bond length \\
\hline $\mathrm{Zn}(1)-\mathrm{O}(5 \mathrm{~A})$ & $2.062(7)$ & $\mathrm{Zn}(2)-\mathrm{O}(5 \mathrm{C})$ & $2.069(7)$ \\
\hline $\mathrm{Zn}(1)-\mathrm{O}(5 \mathrm{~B})$ & $2.062(7)$ & $\mathrm{Zn}(2)-\mathrm{O}(3 \mathrm{~W})$ & $2.079(8)$ \\
\hline $\mathrm{Zn}(1)-\mathrm{O}(1 \mathrm{~W})$ & $2.104(7)$ & $\mathrm{Zn}(2)-\mathrm{O}(1 \mathrm{~S})$ & $2.089(7)$ \\
\hline $\mathrm{Zn}(1)-\mathrm{O}(2 \mathrm{~W})$ & $2.109(8)$ & $\mathrm{Zn}(2)-\mathrm{O}(5 \mathrm{D})$ & $2.103(7)$ \\
\hline $\mathrm{Zn}(1)-\mathrm{O}(3 \mathrm{~B})$ & $2.115(7)$ & $\mathrm{Zn}(2)-\mathrm{O}(3 \mathrm{D})$ & $2.116(8)$ \\
\hline $\mathrm{Zn}(1)-\mathrm{O}(3 \mathrm{~A})$ & $2.154(7)$ & $\mathrm{Zn}(2)-\mathrm{O}(3 \mathrm{C})$ & $2.139(7)$ \\
\hline $\mathrm{O}(1 \mathrm{~A})-\mathrm{C}(1 \mathrm{~A})$ & $1.394(12)$ & $\mathrm{O}(1 \mathrm{C})-\mathrm{C}(1 \mathrm{C})$ & $1.414(14)$ \\
\hline $\mathrm{O}(1 \mathrm{~A})-\mathrm{C}(6 \mathrm{~A})$ & $1.457(11)$ & $\mathrm{O}(1 \mathrm{C})-\mathrm{C}(6 \mathrm{C})$ & $1.443(12)$ \\
\hline $\mathrm{C}(1 \mathrm{~A})-\mathrm{O}(2 \mathrm{~A})$ & $1.191(12)$ & $\mathrm{C}(1 \mathrm{C})-\mathrm{O}(2 \mathrm{C})$ & $1.177(13)$ \\
\hline$C(1 \mathrm{~A})-\mathrm{C}(2 \mathrm{~A})$ & $1.444(13)$ & $C(1 C)-C(2 C)$ & $1.437(13)$ \\
\hline$C(2 A)-C(5 A)$ & $1.391(12)$ & $C(2 C)-C(5 C)$ & $1.390(14)$ \\
\hline$C(2 A)-C(3 A)$ & $1.449(12)$ & $\mathrm{C}(2 \mathrm{C})-\mathrm{C}(3 \mathrm{C})$ & $1.426(15)$ \\
\hline $\mathrm{C}(3 \mathrm{~A})-\mathrm{O}(3 \mathrm{~A})$ & $1.215(12)$ & $\mathrm{O}(3 \mathrm{C})-\mathrm{C}(3 \mathrm{C})$ & $1.236(13)$ \\
\hline $\mathrm{C}(3 \mathrm{~A})-\mathrm{O}(4 \mathrm{~A})$ & $1.337(11)$ & $\mathrm{C}(3 \mathrm{C})-\mathrm{O}(4 \mathrm{C})$ & $1.339(13)$ \\
\hline $\mathrm{O}(4 \mathrm{~A})-\mathrm{C}(4 \mathrm{~A})$ & $1.444(13)$ & $\mathrm{O}(4 \mathrm{C})-\mathrm{C}(4 \mathrm{C})$ & $1.535(16)$ \\
\hline $\mathrm{C}(5 \mathrm{~A})-\mathrm{O}(5 \mathrm{~A})$ & $1.258(11)$ & $\mathrm{C}(5 \mathrm{C})-\mathrm{O}(5 \mathrm{C})$ & $1.259(12)$ \\
\hline$C(5 A)-C(6 A)$ & $1.530(12)$ & $C(5 C)-C(6 C)$ & $1.551(16)$ \\
\hline$C(6 A)-C(7 A)$ & $1.509(14)$ & $C(6 C)-C(7 C)$ & $1.494(17)$ \\
\hline$C(7 A)-C(8 A)$ & $1.371(15)$ & $\mathrm{C}(7 \mathrm{C})-\mathrm{C}(8 \mathrm{C})$ & $1.386(18)$ \\
\hline$C(7 A)-C(12 A)$ & $1.393(14)$ & $\mathrm{C}(7 \mathrm{C})-\mathrm{C}(12 \mathrm{C})$ & $1.385(19)$ \\
\hline $\mathrm{O}(5 \mathrm{~A})-\mathrm{Zn}(1)-\mathrm{O}(5 \mathrm{~B})$ & $90.7(3)$ & $\mathrm{O}(5 \mathrm{C})-\mathrm{Zn}(2)-\mathrm{O}(3 \mathrm{~W})$ & $87.1(3)$ \\
\hline $\mathrm{O}(5 \mathrm{~A})-\mathrm{Zn}(1)-\mathrm{O}(1 \mathrm{~W})$ & $93.9(3)$ & $\mathrm{O}(5 \mathrm{C})-\mathrm{Zn}(2)-\mathrm{O}(1 \mathrm{~S})$ & $94.7(3)$ \\
\hline $\mathrm{O}(5 \mathrm{~B})-\mathrm{Zn}(1)-\mathrm{O}(1 \mathrm{~W})$ & $87.5(3)$ & $\mathrm{O}(3 \mathrm{~W})-\mathrm{Zn}(2)-\mathrm{O}(1 \mathrm{~S})$ & $177.9(4)$ \\
\hline $\mathrm{O}(5 \mathrm{~A})-\mathrm{Zn}(1)-\mathrm{O}(2 \mathrm{~W})$ & $88.3(3)$ & $\mathrm{O}(5 \mathrm{C})-\mathrm{Zn}(2)-\mathrm{O}(5 \mathrm{D})$ & $90.4(3)$ \\
\hline $\mathrm{O}(5 \mathrm{~B})-\mathrm{Zn}(1)-\mathrm{O}(2 \mathrm{~W})$ & $96.4(3)$ & $\mathrm{O}(3 \mathrm{~W})-\mathrm{Zn}(2)-\mathrm{O}(5 \mathrm{D})$ & $93.1(3)$ \\
\hline $\mathrm{O}(1 \mathrm{~W})-\mathrm{Zn}(1)-\mathrm{O}(2 \mathrm{~W})$ & $175.4(3)$ & $\mathrm{O}(1 \mathrm{~S})-\mathrm{Zn}(2)-\mathrm{O}(5 \mathrm{D})$ & $87.9(3)$ \\
\hline $\mathrm{O}(5 \mathrm{~A})-\mathrm{Zn}(1)-\mathrm{O}(3 \mathrm{~B})$ & $174.5(3)$ & $\mathrm{O}(5 \mathrm{C})-\mathrm{Zn}(2)-\mathrm{O}(3 \mathrm{D})$ & $174.2(3)$ \\
\hline $\mathrm{O}(5 \mathrm{~B})-\mathrm{Zn}(1)-\mathrm{O}(3 \mathrm{~B})$ & $90.3(2)$ & $\mathrm{O}(3 \mathrm{~W})-\mathrm{Zn}(2)-\mathrm{O}(3 \mathrm{D})$ & $87.2(3)$ \\
\hline $\mathrm{O}(1 \mathrm{~W})-\mathrm{Zn}(1)-\mathrm{O}(3 \mathrm{~B})$ & $91.5(3)$ & $\mathrm{O}(1 \mathrm{~S})-\mathrm{Zn}(2)-\mathrm{O}(3 \mathrm{D})$ & $91.0(3)$ \\
\hline $\mathrm{O}(2 \mathrm{~W})-\mathrm{Zn}(1)-\mathrm{O}(3 \mathrm{~B})$ & $86.2(3)$ & $\mathrm{O}(5 \mathrm{D})-\mathrm{Zn}(2)-\mathrm{O}(3 \mathrm{D})$ & $88.8(3)$ \\
\hline $\mathrm{O}(5 \mathrm{~A})-\mathrm{Zn}(1)-\mathrm{O}(3 \mathrm{~A})$ & $89.6(3)$ & $\mathrm{O}(5 \mathrm{C})-\mathrm{Zn}(2)-\mathrm{O}(3 \mathrm{C})$ & $90.0(3)$ \\
\hline $\mathrm{O}(5 \mathrm{~B})-\mathrm{Zn}(1)-\mathrm{O}(3 \mathrm{~A})$ & $173.1(3)$ & $\mathrm{O}(3 \mathrm{~W})-\mathrm{Zn}(2)-\mathrm{O}(3 \mathrm{C})$ & $92.6(3)$ \\
\hline $\mathrm{O}(1 \mathrm{~W})-\mathrm{Zn}(1)-\mathrm{O}(3 \mathrm{~A})$ & $85.5(3)$ & $\mathrm{O}(1 \mathrm{~S})-\mathrm{Zn}(2)-\mathrm{O}(3 \mathrm{C})$ & $86.4(3)$ \\
\hline $\mathrm{O}(2 \mathrm{~W})-\mathrm{Zn}(1)-\mathrm{O}(3 \mathrm{~A})$ & $90.5(3)$ & $\mathrm{O}(5 \mathrm{D})-\mathrm{Zn}(2)-\mathrm{O}(3 \mathrm{C})$ & $174.3(3)$ \\
\hline $\mathrm{O}(3 \mathrm{~B})-\mathrm{Zn}(1)-\mathrm{O}(3 \mathrm{~A})$ & $90.0(3)$ & $\mathrm{O}(3 \mathrm{D})-\mathrm{Zn}(2)-\mathrm{O}(3 \mathrm{C})$ & $91.4(3)$ \\
\hline
\end{tabular}

TABLE 3: Hydrogen bonds for $\left[\mathrm{Zn}(\mathrm{L}-\mathrm{H})_{2}\left(\mathrm{H}_{2} \mathrm{O}\right)_{2}\right]\left[\mathrm{Zn}(\mathrm{L}-\mathrm{H})_{2}\left(\mathrm{H}_{2} \mathrm{O}\right)(\mathrm{MeOH})\right] \mathrm{H}_{2} \mathrm{O}\left[\AA\right.$ and $\left.^{\circ}\right]$.

\begin{tabular}{lcccc}
\hline $\mathrm{D}-\mathrm{H} \cdots \mathrm{A}$ & $\mathrm{d}(\mathrm{D}-\mathrm{H})$ & $\mathrm{d}(\mathrm{H} \cdots \mathrm{A})$ & $\mathrm{d}(\mathrm{D} \cdots \mathrm{A})$ & $2.651(11)$ \\
\hline $\mathrm{O}(1 \mathrm{~S})-\mathrm{H}(1 \mathrm{~S}) \cdots \mathrm{O}(2 \mathrm{D}) \# 1$ & 0.85 & 1.80 & $2.651(11)$ & 1.83 \\
$\mathrm{O}(4 \mathrm{~W})-\mathrm{H}(4 \mathrm{WA}) \cdots \mathrm{O}(2 \mathrm{D}) \# 1$ & 0.84 & 2.39 & $2.77(3)$ & 162.3 \\
$\mathrm{O}(4 \mathrm{~W})-\mathrm{H}(4 \mathrm{WB}) \cdots \mathrm{O}(5 \mathrm{~W})$ & 0.89 & $1.84(3)$ & $2.677(10)$ & 106.0 \\
$\mathrm{O}(1 \mathrm{~W})-\mathrm{H}(1 \mathrm{WA}) \cdots \mathrm{O}(2 \mathrm{~B}) \# 2$ & $0.84(2)$ & $1.82(2)$ & $2.685(10)$ & $170.0(13)$ \\
$\mathrm{O}(2 \mathrm{~W})-\mathrm{H}(2 \mathrm{WA}) \cdots \mathrm{O}(2 \mathrm{~A}) \# 3$ & $0.84(2)$ & $1.88(4)$ & $2.698(11)$ & $176.0(13)$ \\
$\mathrm{O}(3 \mathrm{~W})-\mathrm{H}(3 \mathrm{WA}) \cdots \mathrm{O}(2 \mathrm{C}) \# 4$ & $0.83(2)$ & & $168.0(12)$ \\
\hline
\end{tabular}

${ }^{1} \mathrm{H}-\mathrm{NMR}$ spectrum in DMSO- $d_{6}$ of the complex confirms the formation of metal-oxygen bonds since the signal of the acidic proton of the ligand (around $8.65 \mathrm{ppm}$ ) is absent in the metal complex.
3.2. Description of the Structures. The molecular structures of complexes Zn1 and Zn2 are shown in Figures 1 and 2, whereas selected bond lengths and angles as well the hydrogen bond lengths are listed in Tables 2 and 3 consequently. 


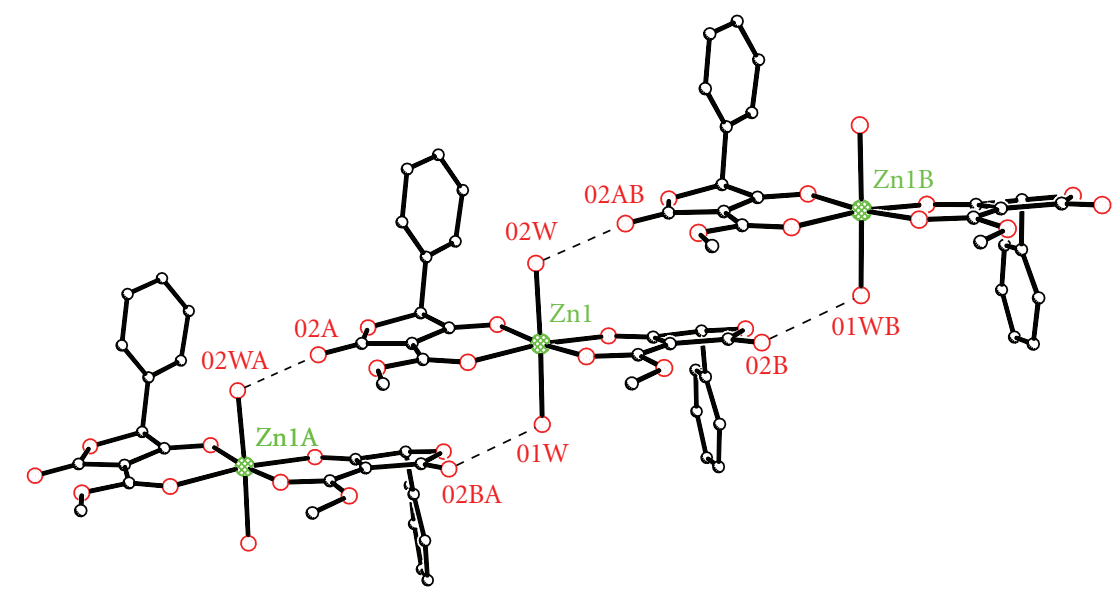

(a)

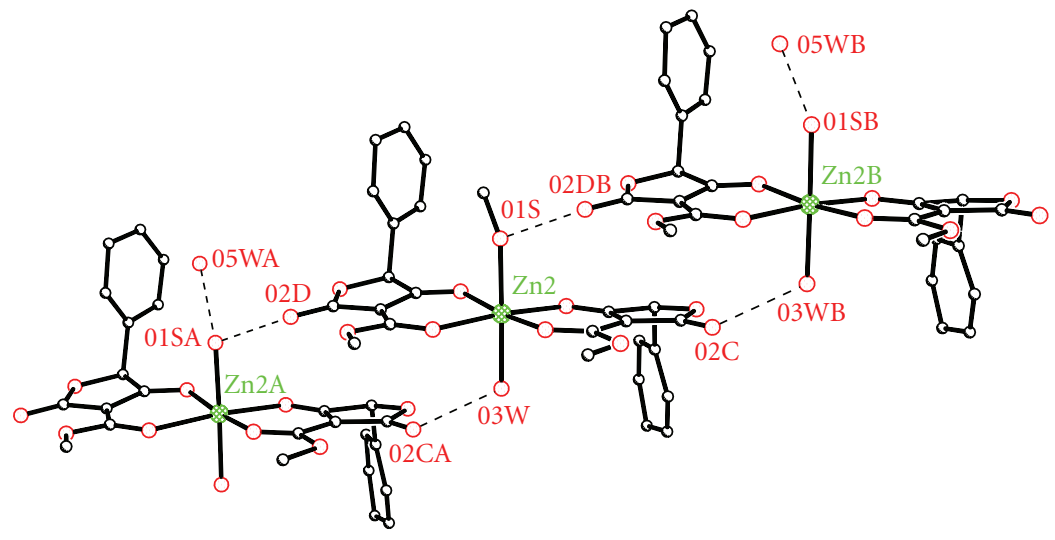

(b)

FigURE 2: X-ray structure of the metal complexes showing the hydrogen bonds.

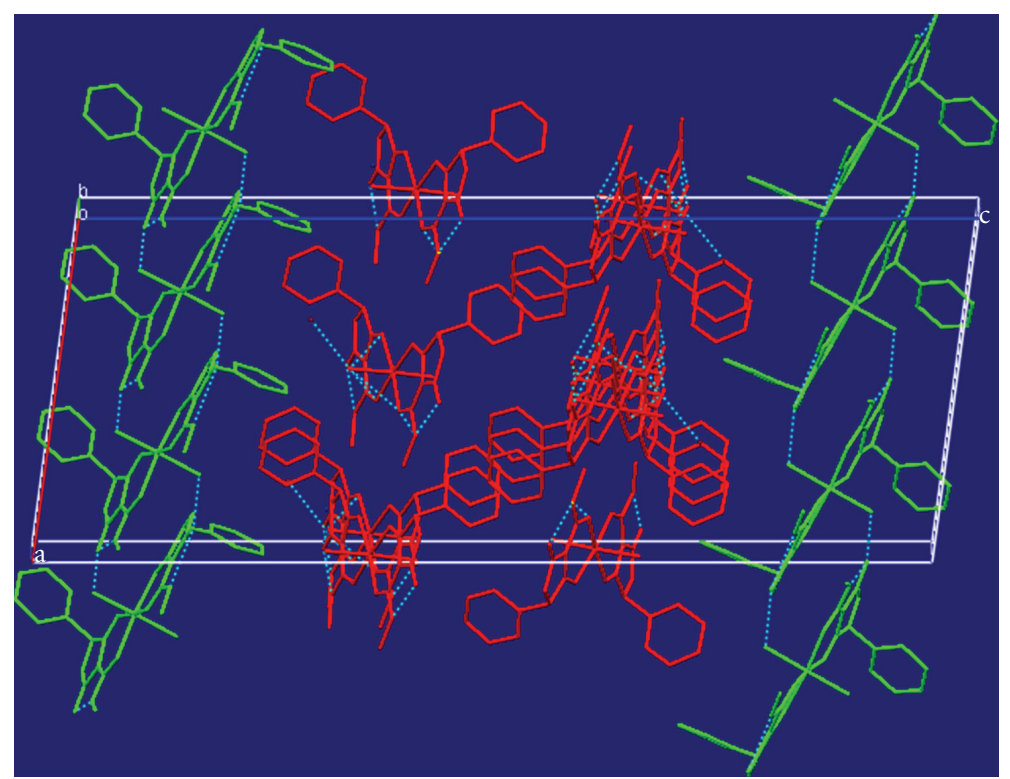

Figure 3: Zn1 chains (red) and Zn2 chains (green). 
The structure was solved in space group C2 and refined as a racemic twin (BASF 0.17) with two similar molecules in the asymmetric unit. The zinc ions are six-coordinate, each coordinated to two monodeprotonated, bidentate ligands which bind through alkoxide and carbonyl groups and are cis to one another. The coordination sphere about $\mathrm{Zn} 1$ is completed by two coordinated water molecules. In the second molecule (containing $\mathrm{Zn} 2$ ), one of the axial sites is disordered and has been modeled as $50: 50$ disorder between methanol and water (with the oxygen atoms on the same site), with a further uncoordinated water molecule hydrogen bonded to the partial occupancy water ligand (Figure 1).

According to the data provided by X-ray Crystallography Analysis, the complex comprises of three different subcomplexes: (a) the $\mathrm{Zn}(\mathrm{L}-\mathrm{H})_{2}\left(\mathrm{H}_{2} \mathrm{O}\right)_{2}$ which is the molecule 1 centered on $\mathrm{Zn} 1$, (b) the $\left.\mathrm{Zn}(\mathrm{L}-\mathrm{H})_{2}\left(\mathrm{H}_{2} \mathrm{O}\right)\right] \mathrm{H}_{2} \mathrm{O}$ which represents the $50 \%$ percentage of molecule 2 centered on $\mathrm{Zn}_{2}$, and (c) the $\mathrm{Zn}(\mathrm{L}-\mathrm{H})_{2}\left(\mathrm{H}_{2} \mathrm{O}\right)(\mathrm{MeOH})$ which represents the other $50 \%$ percentage of molecule 2 centered on $\mathrm{Zn}_{2}$. If we add appropriately the above three complexes (100\% of complex (a) $+50 \%$ of complex (b) $+50 \%$ of complex (c)), then the molecular formula found is $\mathrm{Zn}_{2}(\mathrm{~L}-\mathrm{H})_{4}\left(\mathrm{H}_{2} \mathrm{O}\right)_{4.5}(\mathrm{MeOH})_{0.5}$ or $\mathrm{Zn}_{2} \mathrm{C}_{48.5} \mathrm{H}_{47} \mathrm{O}_{25}$.

Hydrogen bonding between the coordinated water (or methanol) molecules and the uncoordinated carbonyl groups of neighboring molecules link the complexes into one-dimensional chains. Each molecule gives rise to an independent chain, those comprising symmetry equivalents of $\mathrm{Zn} 2$ run parallel to the $\mathrm{b}$ axis, while those composed of symmetry equivalents of $\mathrm{Zn} 1$ lie along the ab diagonal (Figures 2 and 3).

\section{Conclusions}

The use of 3-methoxycarbonyl-5-phenyl tetronic acid in reaction with $\mathrm{Zn}\left(\mathrm{OCOCH}_{3}\right)_{2} \cdot 2 \mathrm{H}_{2} \mathrm{O}$ has yielded two mononuclear $\left[\mathrm{Zn}(\mathrm{L}-\mathrm{H})_{2}\left(\mathrm{H}_{2} \mathrm{O}\right)_{2}\right]$ (1) and $[\mathrm{Zn}(\mathrm{L}-$ $\left.\mathrm{H})_{2}\left(\mathrm{H}_{2} \mathrm{O}\right)(\mathrm{MeOH})\right] \mathrm{H}_{2} \mathrm{O}$ (2), complex compounds. The crystal structure of the complexes shows the existence of two independent molecules in the asymmetric unit in the crystal moiety. The complexation is achieved through the oxygens of the alkoxide groups and the carbonyl functionalities. Hydrogen bonding between water or methanol molecules of the unit gives rise to two one-dimensional independent chains. These models are promising systems for the development of new supramolecular architectures. Design and results on the synthesis of zinc (II) fluorescent probes with chemosensors heterocyclic molecules containing the $\beta$-diketo functionality will be reported in due course.

\section{Acknowledgments}

The authors are grateful to the Science and Technology Facilities Council for access to the SRS at Daresbury. J. Markopoulos would like to thank the National and Kapodistrian University of Athens for financial support (special account for research Grant no. 70/4/3337).

\section{References}

[1] R. Schobert, "Domino syntheses of bioactive tetronic and tetramic acids," Naturwissenschaften, vol. 94, no. 1, pp. 1-11, 2007.

[2] A. L. Zografos and D. Georgiadis, "Synthetic strategies towards naturally occurring tetronic acids," Synthesis, no. 19, pp. 31573188, 2006.

[3] D. Tejedor and F. García-Tellado, "Synthesis and chemistry of tetronic acids," Organic Preparations and Procedures International, vol. 36, no. 1, pp. 33-59, 2004.

[4] S. Peukert, Y. Sun, R. Zhang et al., "Design and structureactivity relationships of potent and selective inhibitors of undecaprenyl pyrophosphate synthase (UPPS): tetramic, tetronic acids and dihydropyridin-2-ones," Bioorganic and Medicinal Chemistry Letters, vol. 18, no. 6, pp. 1840-1844, 2008.

[5] D. H. Davies, E. W. Snape, P. J. Suter, T. J. King, and C. P. Falshaw, "Structure of antibiotic M139603; X-ray crystal structure of the 4-bromo-3,5-dinitrobenzoyl derivative," Journal of the Chemical Society, Chemical Communications, no. 20, pp. 1073-1074, 1981.

[6] R. Schobert and A. Schlenk, "Tetramic and tetronic acids: an update on new derivatives and biological aspects," Bioorganic and Medicinal Chemistry, vol. 16, no. 8, pp. 4203-4221, 2008.

[7] B. E. Roggo, F. Petersen, R. Delmendo, H.-B. Jenny, H. H. Peter, and J. Roesel, "3-alkanoyl-5-hydroxymethyl tetronic acid homologues and resistomycin: new inhibitors of HIV1 protease I. Fermentation, isolation and biological activity," Journal of Antibiotics, vol. 47, no. 2, pp. 136-142, 1994.

[8] G. Pattenden, M. W. Turvill, and A. P. Chorlton, "Maleic anhydrides in synthesis. Preparation of furan-2(5H)-one phosphonate derivatives and a new synthesis of pulvinic acids and pulvinone analogues," Journal of the Chemical Society, Perkin Transactions 1, no. 10, pp. 2357-2361, 1991.

[9] Y. Bourdreux, E. Bodio, C. Willis, C. Billaud, T. Le Gall, and C. Mioskowski, "Synthesis of vulpinic and pulvinic acids from tetronic acid," Tetrahedron, vol. 64, no. 37, pp. 8930-8937, 2008.

[10] G. Athanasellis, O. Igglessi-Markopoulou, and J. Markopoulos, "Tetramic and tetronic acids as scaffolds in bioinorganic and bioorganic chemistry," Bioinorganic Chemistry and Applications, vol. 2010, Article ID 315056, 11 pages, 2010.

[11] M. Sechi, A. Bacchi, M. Carcelli et al., "From ligand to complexes: inhibition of human immunodeficiency virus type 1 integrase by $\beta$-diketo acid metal complexes," Journal of Medicinal Chemistry, vol. 49, no. 14, pp. 4248-4260, 2006.

[12] M. A. V. Ribeiro da Silva, L. M. N. B. F. Santos, and E. Giera, "Standard molar enthalpies of formation of zinc(II) $\beta$ diketonates and monothio- $\beta$-diketonates," Journal of Chemical Thermodynamics, vol. 40, no. 8, pp. 1318-1324, 2008.

[13] M. Doskocz, K. Kubas, A. Frackowiak, and R. Gancarz, "NMR and ab initio studies of $\mathrm{Mg}^{2+}, \mathrm{Ca}^{2+}, \mathrm{Zn}^{2+}, \mathrm{Cu}^{2+}$ alizarin complexes," Polyhedron, vol. 28, no. 11, pp. 2201-2205, 2009.

[14] J. M. Berg, "Zinc fingers and other metal-binding domains. Elements for interactions between macromolecules," Journal of Biological Chemistry, vol. 265, no. 12, pp. 6513-6516, 1990.

[15] P. Jiang and Z. Guo, "Fluorescent detection of zinc in biological systems: recent development on the design of chemosensors and biosensors," Coordination Chemistry Reviews, vol. 248, no. 1-2, pp. 205-229, 2004.

[16] E. L. Que, D. W. Domaille, and C. J. Chang, "Metals in neurobiology: probing their chemistry and biology with 
molecular imaging," Chemical Reviews, vol. 108, no. 5, pp. 1517-1549, 2008.

[17] E. M. Nolan and S. J. Lippard, "Small-molecule fluorescent sensors for investigating zinc metalloneurochemistry," Accounts of Chemical Research, vol. 42, no. 1, pp. 193-203, 2009.

[18] G. Consiglio, S. Failla, P. Finocchiaro, I. P. Oliveri, R. Purrello, and S. Di Bella, "Supramolecular aggregation/deaggregation in amphiphilic dipolar schiff-base zinc(II) complexes," Inorganic Chemistry, vol. 49, no. 11, pp. 5134-5142, 2010.

[19] K. A. Kounavi, M. J. Manos, A. J. Tasiopoulos, S. P. Perlepes, and V. Nastopoulos, "Zinc(II) and nickel(II) benzoate complexes from the use of 1-methyl-4,5-diphenylimidazole," Bioinorganic Chemistry and Applications, vol. 2010, Article ID 178034, 7 pages, 2010.

[20] L. Ooi, Principles of X-Ray Crystallography, Oxford University Press, Oxford, UK, 2010.

[21] E. Gavrielatos, G. Athanasellis, O. Igglessi-Markopoulou, and J. Markopoulos, "Cationic diamineplatinum(II) complexes containing the enolate of N,3-acetyl-4-hydroxypyrrolin-2one," Inorganica Chimica Acta, vol. 344, pp. 128-132, 2003.

[22] E. Gavrielatos, G. Athanasellis, B. T. Heaton et al., "Palladium $(\mathrm{II}) / \beta$-diketonate complexes containing the enolates of $\mathrm{N}$-acetyl-3-acyltetramic acids: crystal structure of the Lewis base adduct, $\left[\mathrm{Pd}(\mathrm{py})_{4}\right](\mathrm{abta})_{2}$," Inorganica Chimica Acta, vol. 351, no. 1, pp. 21-26, 2003.

[23] G. Athanasellis, E. Gavrielatos, O. Igglessi-Markopoulou, and J. Markopoulos, "Novel 'quinolone' metal complexes: synthesis and spectroscopic studies of $\mathrm{Mg}(\mathrm{II}), \mathrm{Zn}(\mathrm{II})$ and $\mathrm{Ba}$ (II) complexes with $\mathrm{N}$-methyl (or NH)-3-acetyl-4-hydroxy quinolin-2-one ligands," Journal of Heterocyclic Chemistry, vol. 40, no. 4, pp. 645-648, 2003.

[24] G. Athanasellis, G. Zahariou, S. Kikionis, O. IgglessiMarkopoulou, and J. Markopoulos, "Coordination behavior of 3-ethoxycarbonyltetronic acid towards $\mathrm{Cu}$ (II) and $\mathrm{Co}$ (II) metal ions," Bioinorganic Chemistry and Applications, vol. 2008, Article ID 547915, 6 pages, 2008.

[25] G. Athanasellis, O. Igglessi-Markopoulou, and J. Markopoulos, "Novel short-step synthesis of optically active tetronic acids from chiral $\alpha$-hydroxy acids mediated by 1-hydroxybenzotriazole," Synlett, no. 10, pp. 1736-1738, 2002.

[26] C. Mitsos, A. Zografos, and O. Igglessi-Markopoulou, "Synthesis of tetronic acid derivatives from novel active esters of $\alpha$-hydroxyacids," Journal of Heterocyclic Chemistry, vol. 39, no. 6, pp. 1201-1205, 2002.

[27] K. C. Prousis, J. Markopoulos, V. Mckee, and O. IgglessiMarkopoulou, "Efficient construction of functionalized 5carboxymethyl tetramic acids using N-Ac-l-aspartic anhydride as chiral building block," Tetrahedron, vol. 66, no. 22, pp. 3944-3950, 2010. 


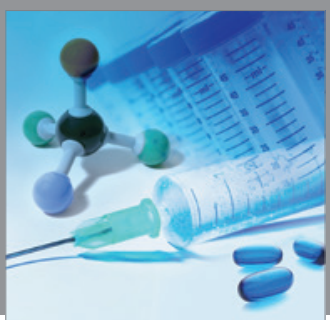

International Journal of

Medicinal Chemistry

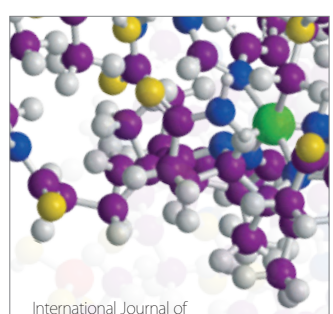

Carbohydrate Chemistry

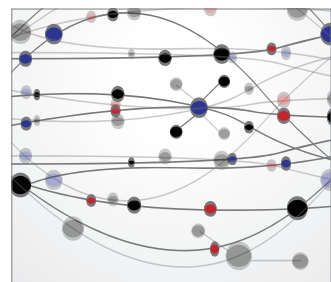

The Scientific World Journal
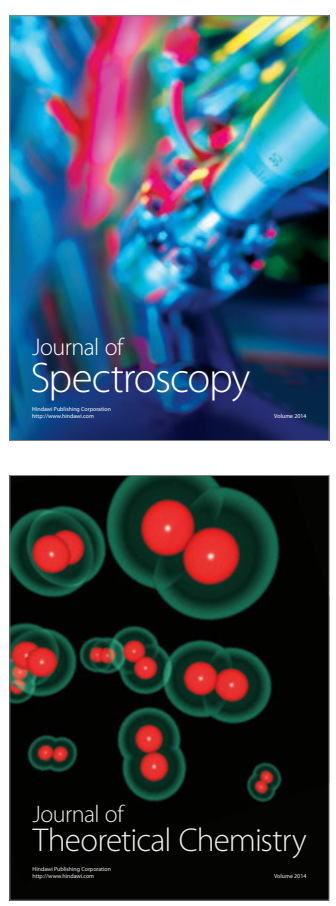
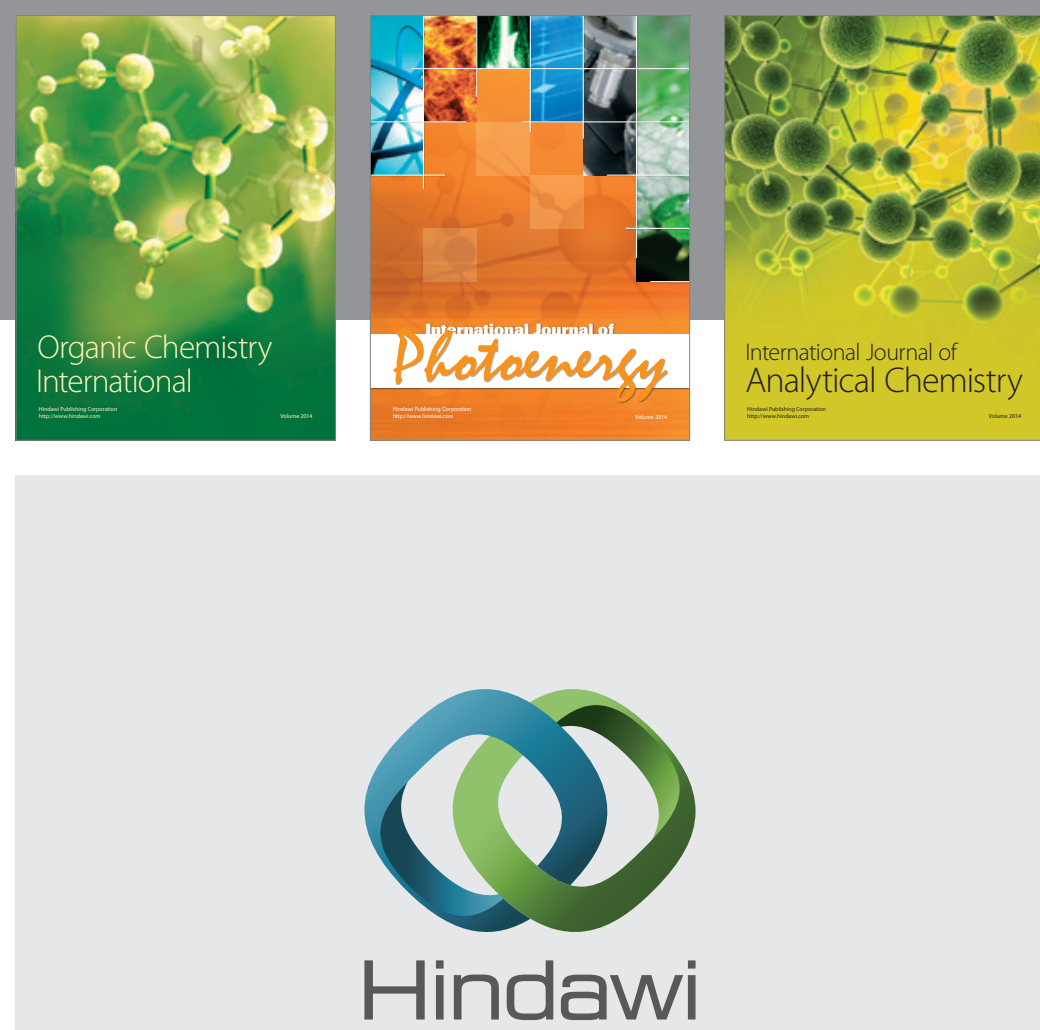

Submit your manuscripts at

http://www.hindawi.com
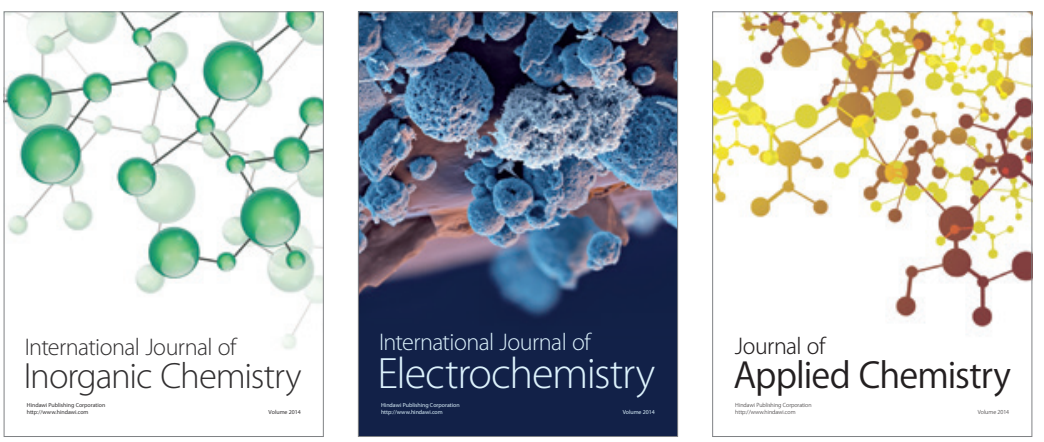

Journal of

Applied Chemistry
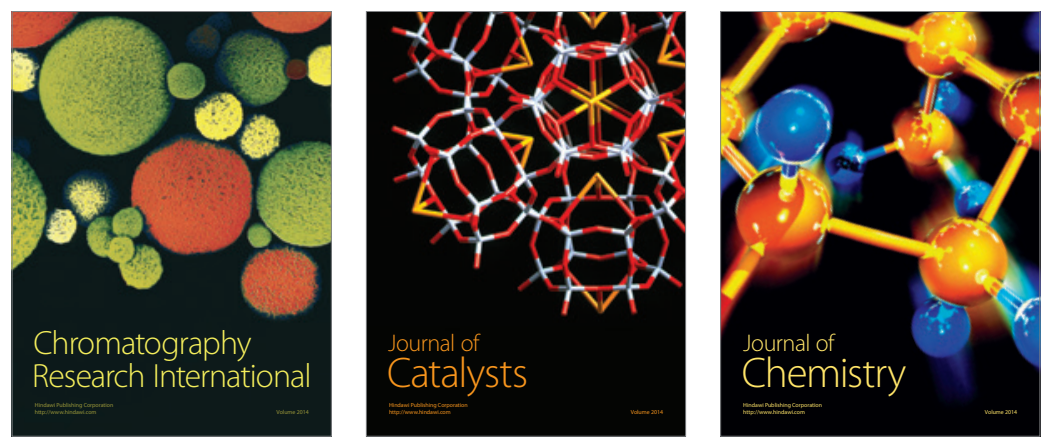
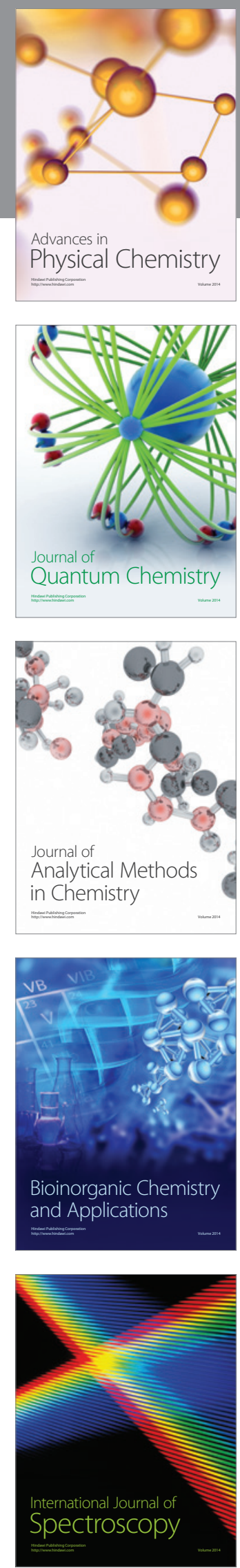